\title{
Low Cost Airline Service Quality Impact on Customer Satisfaction Empirical Study on KSA Market
}

\section{Dr. Mohamed Abdel Kader Abdel Hamid makader@dau.edu.sa}

College of International Transport and Logistics

Arab Academy for Science and Technology and Maritime Transport, Egypt.

Seconded to College of Business Administration

Dar AlUloom University,KSA 


\begin{abstract}
Purpose: Airlines industry growth is essential for any country strives for economic development. Many Arab countries are now using low- cost airline as main pillars to its economic development such as United Arab Emirates, Kingdom of Saudi Arabia and Egypt. In Kingdom of Saudi Arabia the growth of the airlines has great opportunity to be flourishing especially under the 2030 Saudi Arabia new vision. This studyInvestigate the effect of low cost airline service quality on customers' (passengers) satisfaction.

Design/Methodology/Approach: This study adopted convenience sampling and collected 86 passengers located in departure and arrival terminals at King Khaled airport in Riyadh, Kingdom of Saudi Arabia. This study employed the SPSS for data analysis.

Findings: The result revealed that service quality dimensions (reliability, responsiveness, and assurance) have asignificant impact on customers' satisfaction of low-cost airlines while tangibility and empathy have no impact.
\end{abstract}

Practical Implications: The study adds to the body of knowledge about service marketing and quality research.

Key words: service quality, customer satisfaction, low cost airline, KSA2030 


\section{ملخص البحث}

تعتمد العديد من الدول على قطاع الطيران كركيزة للتنمية الاقتصادية كدولة الامارات العربية المتحدة وجمهورية مصر العربية، والمملكة العربية السعودية، وفي إطار رؤية المملكة العربية السعودية الجديدة • ب • r تسعى الحكومة إلى تتشيط قطاع السياحة الداخلية و الدولية للمملكة العربية السعودية؛ و وعليه كان لزاماً التحقق من تأثثر عناصر جودة خدمة في مجال الطيران منخفض التكلفة على رضا العملاء (الركاب) لما لهذا النوع من خطوط الطير ان من جاذبية للأسر منوسطة الدخل.

منهجية البحث: اعتمدت هذه الدراسة على أسلوب العينة الميسرة ، وعدد مفردات العينة القابلة للتحليل الإحصائي 1 ر ر اكبا من صالات الوصول و السفر في مطار الملك خالد بالرياض بالمدلكة العربية السعودية. استخدمت هذه الدر اسة برنامجSPSS لتحليل البيانات.

النتائج: كثنف نتائج الدراسة أن أبعاد جودة الخدمة في الطيران منخفض التكلفة والتي تؤثر على رضا المسافرين على منن هذه الرحلات هي (الموثوقية، والاستجابة، وضمان اندان).

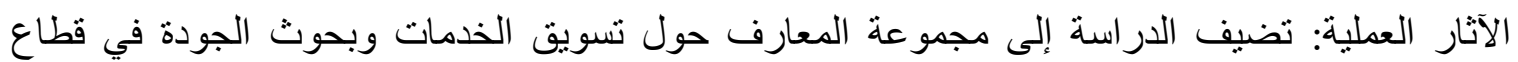
الطير ان منخفض التكلفة، بالاضافة إلى تسليط الضوء على على أهمية توجيه الاستثمار ات في منل هذه النوع من الشركات.

الكلمات المفتاحية: جودة الخدمة، رضا العملاء، الطير ان منخفضة التكلفة، KSA2030 


\section{Introduction}

Airlines industry growth is essential for any country strives for economic development. In Kingdom of Saudi Arabia, the growth of the airlines has great opportunity to be flourishing especially under the 2030 Saudi Arabia new vision. According to last published report from General Authority of Civil Aviation concerning Air Traffic synopsis at Kingdom's Airports during 2015 which shows that the number of passengers at Saudi Arabian airports reached more than 81 million passengers with an increase of $9.5 \%$ over 2014. In addition, the aircraft operations at Kingdom's Airports have increased by $9.8 \%$ over 2014 and reached 646,693 operations. From Schmenner (1986), the airline transportation industry included service factory which had a low degree of interaction and customization, as well as a low degree of labor intensity. On the other hand, this aviation industry in Kingdom of Saudi Arabia government counts on it in its economic reform 2020. KSA aviation industry development one of the main strategic actions on the way to a comprehensive restructuring of the tourism and entertainment sector. Thus, all airlines service providers facing an opportunity to develop its position in the Saudi aviation market.

In Jou et al. (2008) study, he claimed that airline companies adopting service quality for can last for long more than the companies that count on its competitive advantage.

\section{Research Problem}

This research adopted Parasuraman et al. (1988) SERVQUAL dimensions (reliability, tangibility, empathy, responsiveness, and assurance) of low-cost airline services to investigate their impact on passengers' satisfaction in kingdom of Saudi Arabia aviation sector.

\section{Importance of the study}

The importance of this study can be viewed from two perspectives: the academic perspective, and practitioners 'perspective.

From the Academic perspective: although the SERVQUAL variables investigated widely in many service domains (hotels, banks, regular airlines services...) few studies investigated the SERVQUAL variables effect on the satisfaction of low-cost airlines passengers in Saudi Arabia.

From practitioner's perspective:Results of this study will help Low-cost airlines service providers to determine the factors that affect passengers satisfaction based on the quality of services dimensions investigated by this study. In addition, this will assist Low cost airlines companies to improve their customer retention. 


\section{Theoretical framework and literature review}

In order for service companies to enhance their effectiveness and productivity, a lot of attention dedicated to managing service quality. Therefore, service quality is a crucial factor in such turbulent and competitive market (Gilbert \& Wong, 2003). Parasuraman et al. (1985) highlighted the gap between perception and expectation of consumers, by developing 10 components of the service quality (SERVQUAL).In 1988 Parasuraman and his colleagues combined these 10 components of the service quality into five dimensions namely: reliability, assurance, tangibles, empathy, and responsiveness. On the other hand, Cronin and Taylor (1994) criticized the SERVQUAL developed by Parasuraman from the point of the quality of the services received was due to attitudes of the consumers towards the performance of the service. Accordingly, they modified SERVQUAL to SERVPREF. Moreover, a study by Saha and Theingi (2009) showed a significant relationship between air transport passengers' satisfaction and level of the quality of service provided. Um et al. (2006) defined satisfaction as a subjective matter which can be felt as a result of consumer post-purchase evaluation. Researchers Zeithaml et al. (2006), Lovelock et al.(2011), and others suggested that in the airlines' services, the physical evidence (servicescape) has a direct effect on consumer satisfaction and consumer repurchase. Heavily introducing low cost airlines service providers in one country affect the overall airline industry in that country.

Murali noted, (2016) that in perfect competition markets organizations not only focused on its sales process and achieving the planned sales target but became more keen to achieve the targets through achievement of customer satisfaction. This is in order to ensure the long-run relationship with customers, especially in the service sector.

Little studies aimed to build a clear vision on the low cost aviation sector and the quality of the services provided to the customers, through measuring consumer behavior towards quality level of theservice to be obtained (Rajaguru, 2016). The study explored whether the prices of services provided by the low- price airlines are the best prices or not. The study concluded that customers of this type of airlines services were price sensitive and quality of the service is considered a strong indication of customer satisfaction. This study pointed out that the global financial crisis at the beginning of 2000 led to many of the enterprises, especially medium and small enterprises to reduce travel costs, which considered positive transition act and recovery to the low-cost airlines. 
Akan (1995) study on international context has identified seven dimensions to measure the service quality "courtesy and staff efficiency", " communications and transactions", "tangible objects ", " knowledge and understanding of customers", " accuracy and speed in the provision of the service " and " resolve problems". Results of the study indicated that "courtesy" and "staff efficiency" were the most important variables affectingcustomers'evaluation of service quality.

Stauss and Weinlich, (1997) defined the quality of service in different areas, but they agreed with Parasuraman that quality of service resulted from consumer comparison between service quality already receivedfrom the service provider and the quality of service expected before getting the service.On the other hand, Venkatesh \& Nargundkar (2006) argued that quality of service is considered a major factor in the survival and growth of airline sector. Airline companiesoperations include a range of activities that focus on solving clients problems and develop better services. In contrast, Chang \& Yeh (2002) highlighted the difficulty of measuring the quality of services in the aviation sector due to theheterogeneity of the services provided; therefore they recommended that airlines companies must exert more efforts to build long-term relationships with customers.

Sultan and Simpson (2000) study showed that service quality in aviation sector can be measured by identify the difference between customers' expectations and perceived value from the service providers. Another study conducted by Cunnigham (2002) tomeasure airlines service quality frompassengers' point of view by adopted Parasuraman et al. (1988) SERVQUAL. Five dimensionsof SERVQUAL (reliability, tangibility, empathy, responsiveness, and assurance)was adopted to measure the "gap" between customer level of expectations of the service and their opinions of actual received performance.

Ariffin (2010) measured the impact of quality onpassengers' satisfaction. The study concluded that dimensions such as tangibility and responsiveness have the greatest impact on the passengers' satisfaction.

Accordingly the research proposed model is as follows: 


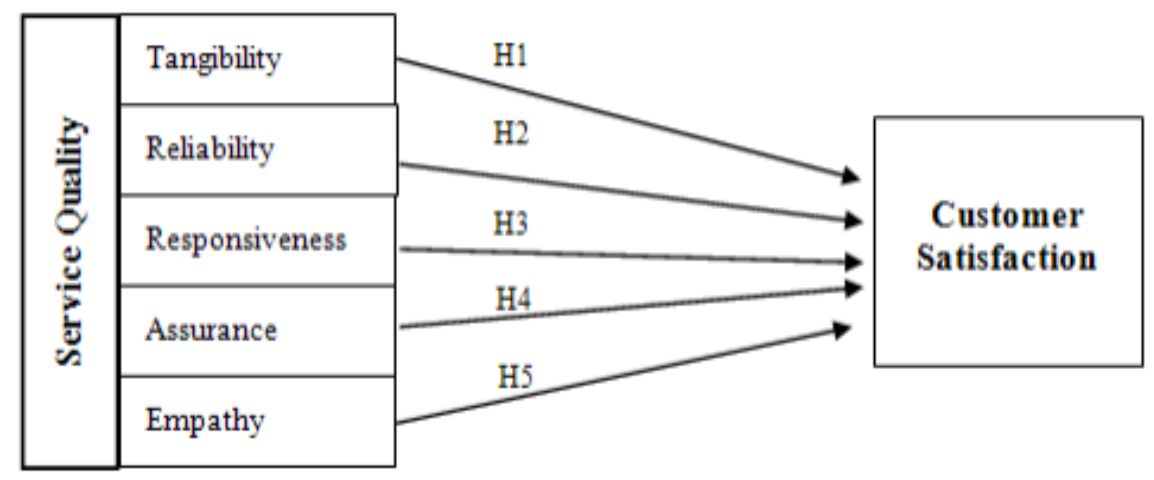

Figure (1) Research proposed model

\section{Methodology}

This study usedtwo samples, one consisted of 35 respondents form the pilot phase and the second sample of the main study consisted of 86 respondents out of 140 with response rate $61 \%$. Both samples were conducted at the King Khaled International Airport during March 2017. Data collection duration was for two weeks. The first week data were collected from 11:00 am to 03:00 PM every day. As for the second week, data were collected from 6:00 pm-9:00 pm. Meeting with passengers through arrivals and departure halls was not easy. Passengers were either in hurry to catch their flights or arriving and have no time to respond to the survey. The researcher tried to overcome this problem and to increase the response rate by adopting an online survey and posted it on Twitter but it was not effective. Accordingly, this affected the response rate. Convenience Sampling was employed for both samples by randomly selected passengers arrived on "Flynas" (domestic or international flights) as considered one of the major low-cost airlines in the Kingdom. This type of sampling was used to address this study for its advantage of being helpful for pilot studies, for hypothesis generation and facilitate data collection in short duration of time (Saunders, M., Lewis, P. \& Thornhill, A. (2012). A self-administrative questionnaire was used for data collection. The questionnaire was divided into six parts to investigate the research problem and 
hypotheses testing. The questions were phrased in the form of statements scored on a 5-point Likert scale as shown in table (1).

\section{Research hypotheses}

There are five hypotheses investigated to address the research problem which are as follows:

H1: Tangibility has a significant impact on customer satisfaction of low-cost airline service.

$\mathrm{H} 2$ : Reliability has a significant impact on customer satisfaction of low- cost airline service.

H3: Responsiveness has a significant impact on customer satisfaction of low- cost airline service.

H4: Assurance has a significant impact on customer satisfaction of low- cost airline service.

H5: Empathy has a significant impact on customer satisfaction of low- cost airline service.

\section{Table (1): Variables Conceptual \& Operational Definitions}

\begin{tabular}{|c|c|c|}
\hline 竞 & \multicolumn{2}{|c|}{$\begin{array}{l}\text { Reliability: Defined as the ability to perform service dependably and } \\
\text { accurately, such as punctuality, efficiency of the check-in process, and } \\
\text { convenience, accuracy of reservations and ticketing (Kim \& Lee, 2011). }\end{array}$} \\
\hline \multirow[b]{2}{*}{ 吾 } & \multirow[b]{2}{*}{$\begin{array}{l}\text { A } 5 \text { Point Likert } \\
\text { scale ranging } \\
\text { from (1) strongly } \\
\text { disagree to (5) } \\
\text { strongly agree } \\
\text { adapted from } \\
\text { (Kang \& James, } \\
\text { 2004) }\end{array}$} & \\
\hline & & $\begin{array}{l}\text { I consider the airline provided services as pr } \\
\text { The airline was dependable in handling cust } \\
\text { service. } \\
\text { I got the services right from the first time. } \\
\text { I got the services at the promised time } \\
\text { Airlines give error-free information. }\end{array}$ \\
\hline
\end{tabular}

\begin{tabular}{|c|c|}
\hline 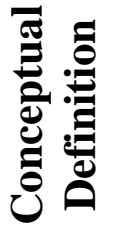 & $\begin{array}{l}\text { Responsiveness: is defined as the willingness to help passengers solve } \\
\text { service problems (flight cancellation and baggage loss), response to } \\
\text { emergency situations, as well as prompt and accurate baggage delivery } \\
\text { (Kim \& Lee, 2011). }\end{array}$ \\
\hline $0=$ & A 5 Point Likert \\
\hline
\end{tabular}




\begin{tabular}{|l|l|l|}
\hline & scale ranging from & Low-cost airline company kept me informed about \\
(1) strongly disagree & when services will be performed. \\
to (5) strongly agree & The service I need provided promptly. \\
adapted from (Kang & Employees were willing to help customers. \\
\& James, 2004) & $\begin{array}{l}\text { Employees were ready to respond to customers' } \\
\text { requests. }\end{array}$ \\
\hline
\end{tabular}

\begin{tabular}{|c|c|c|}
\hline 焉 & \multicolumn{2}{|c|}{$\begin{array}{l}\text { Assurance: is associated with the ability to inspire trust and confidence in } \\
\text { knowledge to answer questions and ensure safe performance, as well as } \\
\text { show courtesy toward passengers (Kim \&Lee, 2011). }\end{array}$} \\
\hline \multirow[b]{2}{*}{ 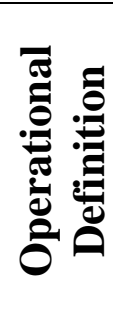 } & \multirow[b]{2}{*}{$\begin{array}{l}\text { A } 5 \text { Point Likert } \\
\text { scale ranging from } \\
\text { (1) strongly disagree } \\
\text { to (5) strongly agree } \\
\text { adapted from (Kang } \\
\text { \& James, 2004) }\end{array}$} & Statements \\
\hline & & $\begin{array}{l}\text { Employees instilled confidence into me. } \\
\text { Employees made me feel safe. } \\
\text { Employees were consistently courteous. } \\
\text { Employees were competent to answer customer } \\
\text { questions. }\end{array}$ \\
\hline
\end{tabular}

\begin{tabular}{|l|l|l|}
\hline \multicolumn{2}{|l|}{$\begin{array}{l}\text { : } \\
\text { : }\end{array}$} & $\begin{array}{l}\text { Empathy: Defined as personal attention to customers, understanding } \\
\text { specific needs of customers, employees and attention provided to them. } \\
\text { (Tahmouri, 2010). }\end{array}$ \\
\hline & $\begin{array}{l}\text { A 5 Point Likert } \\
\text { scale ranging from } \\
\text { (1) strongly disagree }\end{array}$ & $\begin{array}{l}\text { Employees gave customers individual attention. } \\
\text { tomployees deal with customers in a caring } \\
\text { to (5) strongly agree } \\
\text { adapted from (Kang }\end{array}$ \\
\& James, 2004) & $\begin{array}{l}\text { fashion. } \\
\text { Employees deal with customers sincerely. } \\
\text { Employees understand the needs of their } \\
\text { customers. } \\
\text { Flight hours were convenient. }\end{array}$ \\
\hline
\end{tabular}




\begin{tabular}{|l|l|l|}
\hline & $\begin{array}{l}\text { Tangibles: Defined as the physical facilities of the aircraft: seating } \\
\text { comfort, seat space and legroom, in-flight entertainment service } \\
\text { (books, newspapers, movies, games, and magazines), the appearance } \\
\text { of the employees, and meal service (freshness, quantity, and } \\
\text { appearance) (Kim\&Lee, 2011). }\end{array}$ \\
\cline { 2 - 2 } & $\begin{array}{l}\text { A 5 Point Likert } \\
\text { scale ranging } \\
\text { from (1) strongly } \\
\text { disagree to (5) } \\
\text { strongly agree } \\
\text { adapted from } \\
\text { (Kang \& James, } \\
\text { 2004) }\end{array}$ \\
\hline
\end{tabular}

\begin{tabular}{|l|l|l|}
\hline & \multicolumn{2}{|l|}{} \\
\hline & $\begin{array}{l}\text { A 5 Point Likert } \\
\text { scale ranging } \\
\text { from (1) strongly } \\
\text { disagree to (5) }\end{array}$ & $\begin{array}{l}\text { I am satisfied with how the airline had taken } \\
\text { care of me. }\end{array}$ \\
strongly agree & $\begin{array}{l}\text { I am satisfied with this airline. } \\
\text { I enjoyed the travel } \\
\text { adapted from } \\
\text { (Panda and Das, }\end{array}$ & $\begin{array}{l}\text { Overall I am satisfied with the travel experience } \\
\text { through low- cost airlines. }\end{array}$ \\
\hline
\end{tabular}

\section{Data Analysis}

The pilot testing included 35 respondents has been carried out to ensure the reliability of the scale. Cronbach's alpha reliability analysis was conducted to determine the reliability of the measures adopted. Nunnally (1978) has suggested 0.70 as the acceptable level of reliability measure. Alpha values ranged from 0.745 to 0.895 , thus indicating an acceptable level of reliability and the overall reliability of the scale was 0.936 as shown in table(2).

Table (3) Reliability Analysis

\begin{tabular}{|l|c|c|}
\hline $\begin{array}{l}\text { Variab } \\
\text { le } \\
\text { name }\end{array}$ & Scale statements & $\begin{array}{c}\text { Cronbac } \\
\text { h's } \\
\text { Alpha }\end{array}$ \\
\hline
\end{tabular}




\begin{tabular}{|c|c|c|}
\hline : & $\begin{array}{l}\text { - I consider the airline provided services as } \\
\text { promised. } \\
\text { - The airline was dependable in handling } \\
\text { customers' service. } \\
\text { - I got the services right from the first time. } \\
\text { - I got the services at the promised time } \\
\text { - Airlines give error-free information. }\end{array}$ & 0.745 \\
\hline 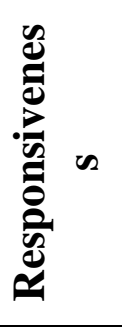 & $\begin{array}{l}\text { - Airline kept me informed about when services } \\
\text { will be performed. } \\
\text { - The service I need provided promptly. } \\
\text { - Employees were willing to help customers. } \\
\text { - Employees were ready to respond to customers' } \\
\text { requests. }\end{array}$ & 0.895 \\
\hline 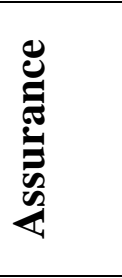 & $\begin{array}{l}\text { - Employees instilled confidence into me. } \\
\text { - Employees made me feel safe. } \\
\text { - Employees were consistently courteous. } \\
\text { - Employees were competent to answer customer } \\
\text { questions. }\end{array}$ & 0.889 \\
\hline 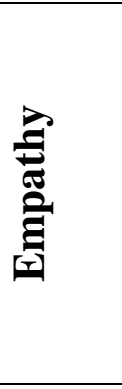 & $\begin{array}{l}\text { - Employees gave customers individual attention. } \\
\text { - Employees deal with customers in a caring } \\
\text { fashion. } \\
\text { - Employees deal with customers sincerely. } \\
\text { - Employees understand the needs of their } \\
\text { customers. } \\
\text { - Flight hours were convenient. }\end{array}$ & 0.701 \\
\hline 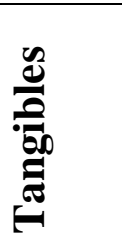 & $\begin{array}{l}\text { - } \quad \text { Facilities were visually appealing. } \\
\text { - Employees had a neat, professional appearance. } \\
\text { - Materials were visually appealing. }\end{array}$ & 0.821 \\
\hline 莺 & $\begin{array}{l}\text { - I am satisfied with how the airline had taken care } \\
\text { of me. } \\
\text { - I am satisfied with this airline. } \\
\text { - I enjoyed the travel } \\
\text { - Overall I was satisfiedwith the travel experience } \\
\text { through low-cost airline. }\end{array}$ & 0.895 \\
\hline \multicolumn{2}{|r|}{ Overall Reliability } & 0.944 \\
\hline
\end{tabular}

\section{Demographic Profile}


The response rate of the questionnaire was $70 \%$ resulted from 84 respondents accept to fill the distributed surveys. 14 Female respondents were included compared to 70 male respondents average mean age was 30 years old. Whereas $13 \%$ of them wereSaudis workingin public sector jobs and the $87 \%$ were working in private sector. This $87 \%$ consisted of $35 \%$ Saudis and $65 \%$ non-Saudis. Cross tabulation analysis was adopted to enhance the understanding of research sample as follows:

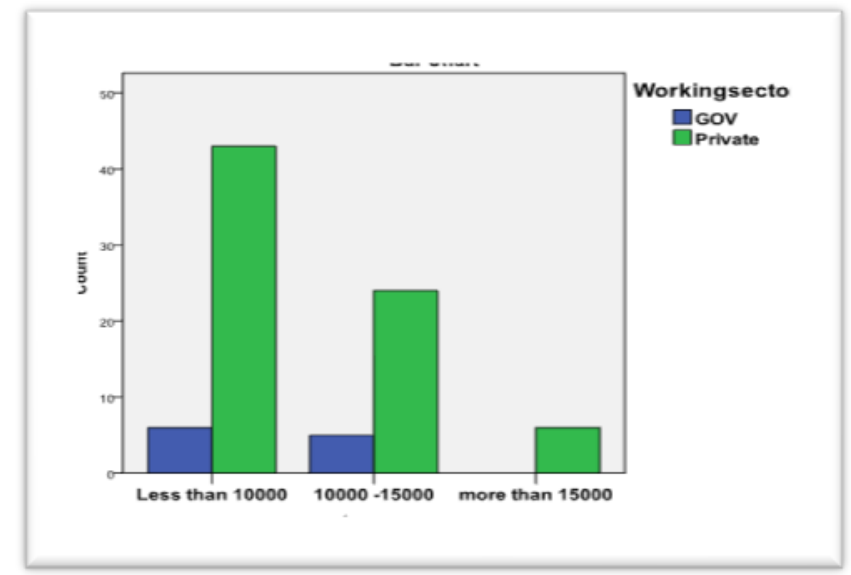

Figure ( 2 ) Passenger monthly income and type of working sector

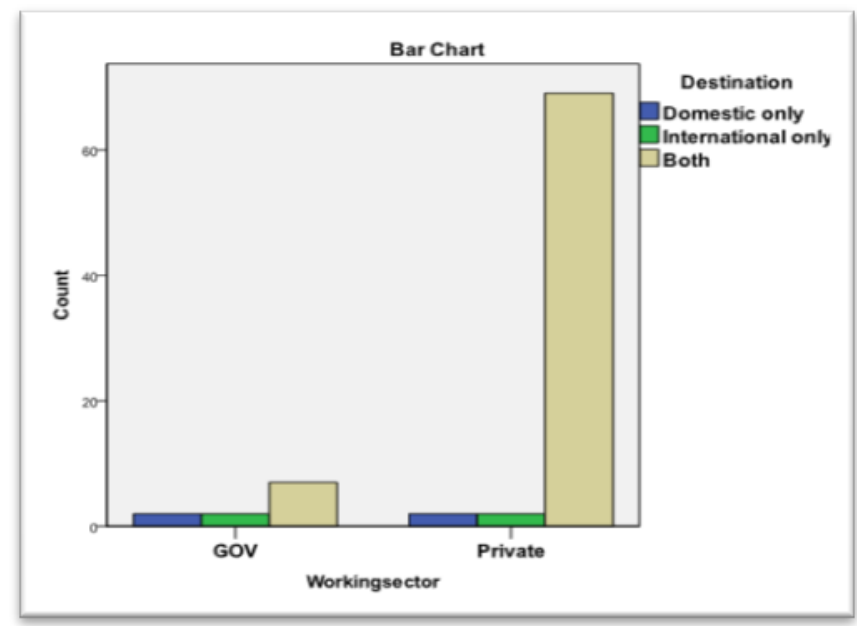

Figure (3) Passenger Working sectors and Travelling Destination

Figure (2) shows that Public sector according to the sample analysis has lower monthly income compared to the private sector monthly income. Additionally, Figure (3) shows that the private sector counting more on the low-cost airlines in its international and domestic flights compared to the government sector.

\section{Research Hypotheses Testing}


The regression results reported in Table (4) showed that three of the service quality dimensionsexplained $46 \%$ of the customer satisfaction towards the low cost airline services $(F=13,739 p<0.000)$,thereby confirming the fitness of the model. Data analysis shows that empathy has the strongest effect on thecustomer satisfaction $(\beta=0.889, p<0.000)$, followed by staff responsiveness $(\beta=0.481$, $p<0.03)$ and assurance $(\beta=0.461, p<0.04)$. However, Tangibles and Reliability dimensions were found to be insignificanttowards low-cost airline customer satisfaction.

Table (4): Coefficients

\begin{tabular}{|c|c|c|c|c|}
\hline Hypothesis & B & SE & $\beta$ & p-value \\
\hline $\mathrm{H}_{1}$ & .911 & .168 & .191 & .154 \\
\hline $\mathrm{H}_{2}$ & 2.877 & 1.690 & .134 & .264 \\
\hline $\mathrm{H}_{3}$ & .126 & .112 & .481 & .033 \\
\hline $\mathrm{H}_{4}$ & .492 & .227 & .461 & .041 \\
\hline $\mathrm{H}_{5}$ & .424 & .204 & .889 & .000 \\
\hline
\end{tabular}

\section{Discussion and Conclusion}

This research attempts to examine Parasuraman quality dimensions and their effect on customer satisfaction of low-cost airlines. In order to achieve the research aim, hypotheses were tested. Based on the previous studies quality dimensions have an impact on customers satisfaction. The results revealed thatempathy, responsiveness and assurance were the main determinants of customer satisfaction of low-cost airlines. Findings showed that the ability to satisfy customers were driven more by empathy as in personal attention given to customers and understanding their specific needs. This is in line with several studies applied to different services such asAriffin et al. (2010), Suhartanto et al. (2012) and Khan (2014).

Though low-cost airlines succeeded in attracting customers who are characterized by being price sensitive they found difficulties in building customer satisfaction. Especially the fact that price sensitive consumers can easily switch from one airlines to the others for better prices (Periera et al., 2011). Identifying the factors that affect customers' satisfaction of low-cost airline are crucial because in travel industry, satisfied customers are more likely to travel on the same airlines in the future and willing to participate in loyalty programs. Moreover, they will more likely recommend the airlines to others and will engage in more positive WOM compared to dissatisfied customers (Carpenter, 2008; Hui et al., 2007). Service quality not only contributes to the success of firms but also their continuing in the industry while holding a good reputation. 


\section{Managerial implication}

According to the literature, the growth of low-cost airlines in a country depends on key success factors such as the quality of the service being provided, loyalty programs, the availability and the variety of the schedules being offered on the airlines. The results of the study provide managers information about what they should consider while designing or developing their business especially in Saudi Arabia where the competition between different low-cost airlines is high. In order for low-cost airlines to stay in the business, they reduced their operational cost so that they would be able to charge customers with low prices but they cannot reduce the quality level. This is due to the existence of high competition not only from full cost airlines but also with other similar low-cost airlines operating in the country. Therefore the aviation companies should ensure the modernization of their equipment, plane interior design, the appearance of the crew and the quality of meals and refreshments. In addition, aviation companies should respond to the passengers' needs instantly. According to the study, it was shown that the public sector salaries are less compared to private one which is considered an opportunity for low-cost airlines to promote their services to the public sector. This can be an opportunity for low cost airlines to target the government sector which is under the economic reform 2020 plan.

\section{Limitationsand direction for future research}

The sample size is small although it is considered close to the sample size of other SERVQUAL studies this affect generalization of the results. This study also considered only domestic flights as well as small number of international trips.

\section{References}

Akan, P. (1995). Dimensions of service quality: a study in Istanbul, Managing service quality, MCB University Press, Vol.5, Number 6, p.39-43.

Ariffin, A. A. M., Salleh, A. H. M., Aziz, N. A., \& Asbudin, A. A. (2010). Service quality and satisfaction for low cost carriers. International Review of Business Research Papers, 6(1), 47-56.

Carpenter, J.M.(2008). Consumer shopping value, satisfaction and loyalty in discount retailing. J. Retail. Consumer. Serv. 15, 358-363

Chang, Y.H., and Yeh, C.H. (2002). A survey analysis of service quality for domestic airlines. European Journal of Operational Research. 139, p166-177.

Cronin, J. J., \& Taylor, S. A. (1994) Measuring service quality; a re-examination and extension. The Journal of Marketing, Vol. 56, Number 3, p.55-68.

Cunningham, L.F., Young, C.E. and Lee, M.(2002). Cross-cultural be ensured of service quality and risk in air transportation should be listed. 
Hui, T.K., Wan, D., Ho, A. (2007). Tourists' satisfaction, recommendation and revisiting. Singapore. Tour. Manag. 28, 965-975.

J.C. Nunnally. Psychometric theory (2nd ed.). New York: McGraw-Hill. 1978.

Jou, R-C., S-H. Lam, D. Hensher, C-C. Chen, and C-W. Kuo. (2008). The effect of service quality and price on international airline competition. Transportation Research (part E): 580-592

Kang, G.-D., James, J.J. (2004). Service quality dimensions: an examination of Gro“nroos's service quality model”, Managing Service Quality, Vol. 14 No. 4, pp. 266-77.

Khan, U., \& Khan, N. (2014). Customer Satisfaction in Airline Industry. International Proceedings of Economics Development and Research, 76, 63.

Kim, Y. K., \& Lee, H. R. (2011). Customer satisfaction using low cost carriers. Tourism Management, 32(2), 235-243.

Lovelock, C., and J. Wirtz. (2011). Services Marketing People, Technology, Strategy. (7th ed.). Pearson International Edition: 27-37, 160. 277, 280-283

Murali, S., Pugazhendhi, S. and Muralidharan, C.(2016). Modelling and Investigating after sales service quality with customer satisfaction, rétention" and loyalty,-A case study of home appliances business. Journal of Retailing and Consumer Services, 30, pp.67-83.

Panda, T.K., Das, S.(2015). The role of intangibility in service quality and its impact on customer satisfaction: a comparative study of hospital and hospitality sectors. IUP J. Mar. Manag. XIII, 53e69

Parasuraman, A.zeithmal,V.A.and. Berry,L.L.(1988)" Servqual: a multi-item scale for measuring Consumer perceptions of service Quality, Journal of Retailing Vol.64,No.1, p12-37

Periera, C.F., Porenca, A.P.A., Reis, F.L. (2011). Regular airlines flying towards a low cost strategy. Int. Bus. Res. 4, 93 -99.

Rajaguru, R. (2016). Role of value for money and service quality on behavioural intention: A study of full service and low cost airlines. Journal of Air Transport Management, 53, pp.114-122.

Saha, G.C., Theingi (2009). Service quality, satisfaction, and behavioural intentions. Manag. Serv. Qual. 19 (3), 350e372.

Schmenner, R.W. (1986). How can service businesses survive and prosper? Sloan Management Review, Vol. 27 No. 3, pp. 21-32. 
Stauss, B., Weinlich, B. (1997). Process-oriented measurement of service quality: applying the sequential incident technique. European Journal of Marketing 31 (1), 33-55.

Suhartanto, D., \& Noor, A. A. (2012). Customer satisfaction in the airline industry: the role of service quality and price. In Asia Tourism Forum Conference (p. 6).

Sultan, F., Simpson Seafood, M.C.(2000). International service variants: an information processing system is passenger expectations and career of service quality. J. Serv. Mark. 14 (3), wifs e 216.

Saunders, M., Lewis, P. \& Thornhill, A. (2012) "Research Methods for Business Students" 6th edition, Pearson Education Limited

Tahmouri ,M.A.(2010). Service quality measurement of the social security organization in Guilan based on Servqual model (case study: the social security branches in Rasht), Master of Business Administration thesis, Islamic Azad University.

Um S, Chon K, Ro YH. (2006). Antecedents of revisit intention. Annals of Tourism Research 33(4): 1141-1158.

V.A. Parasuraman, A. Zeithaml, L. Berry.( 1985) A Conceptual Model of Service Quality and Its Implications for the Future Research. Journal of Marketing. Vol. 49, pp.41-50.

Venkatesh, B. \& Nargundkar, R. (2006). Service Quality career of Domestic Consumers an information processing system is in India: An empirical study. Journal of Management, Dept. of Management Studies, Bangalore.

Zeithaml,V. and Parasuraman, A. (2006). Understanding and Improving Service Quality: A Literature Review and Research Agenda, in Weitz.B and Wensley, R. (Ed.), Handbook of Marketing. London: Sage Publications. 